\title{
KORELASI UKURAN-UKURAN TUBUH DAN VOLUME AMBING DENGAN PRODUKSI SUSU KAMBING PERANAKAN ETAWAH DI KECAMATAN METRO TIMUR
}

\section{Correlation of Body Measurements and Udder Volume with Milk Production of Etawah Crossbreed in East Metro District}

\author{
Wahyu Puji Santoso ${ }^{1}$, M Dima Iqbal Hamdani ${ }^{2}$, Arif Qisthon ${ }^{2}$, and Sulastri ${ }^{2}$ \\ ${ }^{1}$ Alumni of Department of Animal Husbandry, Faculty of Agriculture, University of Lampung \\ ${ }^{2}$ Department of Animal Husbandry, Faculty of Agriculture, University of Lampung \\ Soemantri Brojonegoro No.1 Gedong Meneng Bandar Lampung 35145 \\ e-mail : wahyupujisantoso30@gmail.com
}

\begin{abstract}
This research aimed to determine the relationship between body measurements including body length $\left(\mathrm{x}_{1}\right)$, body height $\left(\mathrm{x}_{2}\right)$, chest circumference $\left(\mathrm{x}_{3}\right)$, and udder volume (before milking $\left(\mathrm{x}_{4}\right)$ ) with milk production of Etawah Crossbreed goat at the Mandiri Jaya Bersama and Yosomukti farms, Metro Timur District from July-August 2019. This study used a survey method with twenty female Etawah Cross Breed goats as samples taken by purposive sampling. Data were analyzed using correlation and linear regression analysis. The results showed that volume of udder before milking has a strong relationship $(\mathrm{r}=$ 0.82 ) with milk production, with regression line equation $\hat{Y}=109,65+0,82 \mathrm{X}_{4}\left(\mathrm{R}^{2}=0.66\right)$. Each of body length $(r=0,09)$, body height $(r=0,09)$, or chest circumference $(r=0,18)$ variables were very low correlated with milk production. Combination variables of body length, body height, chest circumference, and udder volume before milking had a strong correlation with milk production, with $\mathrm{r}=0.832$ and the regression line equation of $\hat{\mathrm{Y}}=172,457-16,322 \mathrm{X}_{1}+5,414 \mathrm{X}_{2}+8,361 \mathrm{X}_{3}+0,845 \mathrm{X}_{4}\left(\mathrm{R}^{2}=0.68\right)$. It can be concluded that volume of udder before milking can be used in the estimation of milk production of Etawah Crossbreed goat.
\end{abstract}

Keywords: Etawah Crossbreed, Correlation, Regression, Body measurements, Milk production

\begin{abstract}
ABSTRAK
Penelitian bertujuan untuk mengetahui hubungan antara ukuran-ukuran tubuh yang meliputi panjang badan $\left(\mathrm{x}_{1}\right)$, tinggi badan $\left(\mathrm{x}_{2}\right)$, lingkar dada $\left(\mathrm{x}_{3}\right)$, serta volume ambing (sebelum pemerahan $\left.\left(\mathrm{x}_{4}\right)\right)$ dengan produksi susu kambing Peranakan Etawah (PE) di peternakan rakyat Mandiri Jaya Bersama dan Yosomukti, Kecamatan Metro Timur dari bulan Juli-Agustus 2019. Penelitian ini menggunakan metode survei dengan dua puluh ekor kambing PE betina sebagai sampel yang diambil secara purposive sampling. Data dianalisis dengan analisis korelasi dan regresi linier. Volume ambing sebelum pemerahan memiliki hubungan yang kuat dengan produksi susu, dengan $r=0,815$ dan persamaan garis regresi $\hat{\mathrm{Y}}=$ $109,648+0,818 \mathrm{X}_{4}\left(\mathrm{R}^{2}=66,42 \%\right)$. Peubah panjang badan $(0,089)$, tinggi badan $(0,089)$, atau lingkar dada $(0,184)$ berkorelasi sangat rendah dengan produksi susu. Secara bersama-sama peubah panjang badan, tinggi badan, lingkar dada, dan volume ambing sebelum pemerahan memiliki korelasi yang kuat dengan produksi susu, dengan $\mathrm{r}=0,832 ; \mathrm{R}^{2}=68,20 \%$; dan persamaan garis regresi $\hat{\mathrm{Y}}=172,457-$ $16,322 \mathrm{X}_{1}+5,414 \mathrm{X}_{2}+8,361 \mathrm{X}_{3}+0,845 \mathrm{X}_{4}$. Kesimpulan penelitian ini adalah bahwa volume ambing sebelum pemerahan dapat dipakai dalam pendugaan produksi susu kambing PE.
\end{abstract}

Kata kunci: Kambing Peranakan Etawa, Korelasi, Regresi, Ukuran-ukuran tubuh, Produksi susu

\section{PENDAHULUAN}

Perkembangan peternakan kambing sebagai penghasil daging dan susu saat ini sudah berkembang cukup pesat. Hal tersebut terbukti dari banyak didirikannya peternakan kambing meskipun hanya dalam skala kecil (peternakan rakyat) untuk membantu memenuhi kebutuhan daging dan susu di kalangan masyarakat yang semakin meningkat setiap tahunnya. Usaha ternak kambing perah di Indonesia saat ini mulai meningkat. Peternak mulai 
sadar bahwa kambing perah memiliki potensi yang tinggi untuk dikembangkan. Peningkatan ini dapat membantu kegiatan pemerintah dalam memenuhi kebutuhan akan protein hewani terutama susu.

Kambing PE merupakan hasil persilangan antara kambing kacang (lokal) dengan kambing Etawah (impor) (Sodiq dan Abidin, 2009). Diantara jenis-jenis kambing perah yang ada saat ini, kambing PE termasuk tipe kambing perah unggul karena memiliki kemampuan memproduksi susu sebanyak 1,5-3 liter/hari. Kemampuan tersebut membuat kambing PE cukup signifikan untuk dikembangkan sebagai ternak penghasil susu yang sangat potensial. Faktor kemampuan adaptasi yang tinggi pada kambing PE terhadap kondisi di Indonesia merupakan salah satu alasan jenis ternak tersebut banyak dipilih peternak. Kelebihan dari kambing PE sebagai penghasil susu antara lain modal yang dibutuhkan lebih sedikit, tidak memerlukan lahan luas dan pembudidayaannya relatif mudah, sehingga dapat dijadikan bisnis keluarga dalam upaya peningkatan pendapatan keluarga. Kambing perah mempunyai produktivitas yang dipengaruhi oleh faktor genetik, pakan, manajemen pemeliharaan dan lingkungan yang saling berkaitan. Apabila genetik ternak sudah baik namun manajemen pemeliharaan masih kurang baik maka produktivitas ternak dalam memproduksi susu tidak akan optimal, begitu juga apabila pakan yang diberikan tidak memenuhi kebutuhan ternak maka kualitas serta produktivitas ternak dalam memproduksi susu akan menurun.

Pengetahuan mengenai penampilan ternak kambing PE bibit unggul menjadi suatu hal yang mutlak dalam rangka meningkatkan daya produksi ternak baik susu maupun daging. Taksiran kemampuan seekor ternak dalam memproduksi susu dapat diketahui melalui pemanfaatan kriteria ukuran-ukuran tubuh (Krismanto, 2011). Salah satu cara untuk memilih ternak dapat dilakukan dengan melihat catatan (rekording) produksi ternak. Namun hal tersebut jarang dilakukan karena beberapa peternakan tidak memiliki catatan produksi ternak sebagai informasi produktivitas ternak, maka dalam memilih kambing PE dapat dilakukan dengan cara lain yaitu dengan memperhatikan bentuk dan bagian-bagian tubuh luar (eksterior) mulai dari lingkar dada, panjang badan dan tinggi badan kambing (Pabana, 2010). Ukuran tubuh ternak merupakan cerminan pertumbuhan dan perkembangan ternak sehingga diharapkan dapat memberikan gambaran mengenai penampilan produksi yang dihasilkan (Taofik dan Depison, 2008). Cara mengetahui produksi susu suatu ternak yang dihasilkan selain menggunakan ukuran-ukuran tubuh, dapat juga memilih ternak dengan cara mengukur volume ambing ternak sehingga akan diperoleh gambaran produksi susu ternak tersebut. Pertumbuhan ternak dinyatakan dengan perubahan-perubahan dimensi tubuh seperti bertambahnya tinggi badan, tinggi badan dan ukuran lingkar dada. Berdasarkan permasalahan tersebut maka dilakukan penelitian untuk mengetahui hubungan antara ukuran-ukuran tubuh kambing yaitu meliputi panjang badan $\left(\mathrm{x}_{1}\right)$, tinggi badan $\left(\mathrm{x}_{2}\right)$, dan lingkar dada $\left(\mathrm{x}_{3}\right)$, serta volume ambing $\left(\mathrm{x}_{4}\right)$ dengan produksi susu kambing PE di Metro Timur.

\section{MATERI DAN METODE}

Penelitian ini dilaksanakan pada JuliAgustus 2019. Penelitian dilakukan di kelompok ternak Mandiri Jaya Bersama di Kelurahan Yosodadi dan kelompok ternak Yosomukti di Kelurahan Tejosari Kecamatan Metro Timur.

\section{Materi Penelitian}

Materi yang digunakan dalam penelitian ini adalah 20 ekor kambing PE betina sehat, periode laktasi II-IV, umur 24-42 bulan (berdasarkan kondisi 4-8 gigi seri permanen), dan frekuensi pemerahan satu kali. Peralatan yang digunakan yaitu pita ukur butterfly dengan ketelitian $0,1 \mathrm{~cm}$ dengan panjang $0-150 \mathrm{~cm}$ untuk mengukur lingkar dada, tongkat ukur dengan ketelitian $0,1 \mathrm{~cm}$ dengan panjang 0-150 cm untuk mengukur panjang badan dan tinggi pundak, tempat penampung air berkapasitas 10 liter, tempat penampung air kapasitas 2 liter untuk mengukur volume ambing dan 1 liter air untuk mengukur jumlah produksi susu.

\section{Metode Penelitian}

Penelitian ini diawali dengan survei satu bulan sebelum penelitian berlangsung. Prosedur sampel kambing ditetapkan secara sengaja (purposive sampling) dengan kriteria kambing sehat, periode laktasi II-IV, bulan laktasi I-VI, dan umur 24-42 bulan (berdasarkan kondisi 4-8 gigi seri permanen).

\section{Peubah yang Diamati}

Peubah yang diamati pada penelitian ini adalah panjang badan, tinggi badan, lingkar dada, volume ambing, dan produksi susu. Pengukuran panjang badan, tinggi badan, dan lingkar dada dilakukan menurut Krismanto (2011), sedangkan pengukuran volume ambing menggunakan metode 
"Air Tumpah" berdasarkan Pribadiningtyas et al. (2012).

\section{Analisis Data}

Nilai keeratan ukuran-ukuran tubuh akan dianalisis menggunakan analisis korelasi, determinasi, analisis regresi linier sederhana dan regresi linier berganda. Adapun persamaan yang digunakan (menurut ....) , yaitu:

1. Koefisien korelasi

$$
\mathbf{r}=\frac{n \sum x y-\left(\sum x\right)\left(\sum y\right)}{\sqrt{\left\{n \sum x^{2}-\left(\sum x\right)^{2}\right\}\left(n \sum y^{2}-\left(\sum y\right)^{2}\right\}}}
$$

Keterangan:

$\mathrm{r}=$ Koefisien korelasi

$\mathrm{y}=$ Variabel tidak bebas (produksi susu)

$\mathrm{x}=$ Variabel bebas (ukuran tubuh dan volume ambing)

$\mathrm{n}=$ Jumlah sampel

2. Koefisien determinasi

$$
\mathbf{R}^{2}=\mathbf{r}^{2} \times 100 \%
$$

Keterangan:

$\mathrm{R}=$ Koefisien determinasi

$\mathrm{r}=$ Koefisien korelasi

3. Regresi linier sederhana

$$
\hat{\mathbf{Y}}=\boldsymbol{\beta}_{\mathbf{0}}+\boldsymbol{\beta}_{\mathbf{x}}
$$

Keterangan :

$\hat{\mathrm{Y}}=$ Produksi susu

$\mathrm{X}=$ Peubah bebas (panjang badan, tinggi, badan, lingkar dada dan volume ambing)

$\beta_{0}=$ Intersep

$\beta_{\mathrm{x}}=$ Koefisien regresi produksi susu $(\hat{\mathrm{Y}})$ terhadap ukuran tubuh $(\mathrm{X})$

4. Regresi linear berganda

$$
\hat{\mathbf{Y}}=\boldsymbol{\beta}_{0}+\boldsymbol{\beta}_{1} \mathbf{x}_{1}+\boldsymbol{\beta}_{2} \mathbf{x}_{2}+\ldots+\boldsymbol{\beta}_{n} \mathbf{x}_{\mathbf{n}}
$$

Keterangan :

$\hat{\mathrm{Y}}=$ Produksi susu

$\mathrm{X}=$ Peubah bebas (panjang badan, tinggi badan, lingkar dada dan volume ambing)

$\beta_{0}=$ Intersep

$\beta_{1}=$ Koefisien regresi produksi susu $(\hat{Y})$ terhadap ukuran tubuh $1\left(\mathrm{X}_{1}\right)$

$\beta_{2}=$ Koefisien regresi produksi susu $(\hat{\mathrm{Y}})$ terhadap ukuran tubuh $2\left(\mathrm{X}_{2}\right)$

$\beta_{3}=$ Koefisien regresi produksi susu $(\hat{Y})$ terhadap ukuran tubuh $\mathrm{n}\left(\mathrm{X}_{\mathrm{n}}\right)$

\section{HASIL DAN PEMBAHASAN}

\section{Produksi Susu dan Ukuran-Ukuran Tubuh Kambing PE Betina}

Berdasarkan hasil penelitian ini diperoleh rataan ukuran-ukuran tubuh kambing PE betina di peternakan rakyat Mandiri Jaya Bersama dan Yosomukti yang dapat dilihat pada Tabel 1 .

Tabel 1. Rataan produksi susu dan ukuran-ukuran tubuh kambing PE betina di peternakan rakyat Mandiri Jaya Bersama dan Yosomukti

\begin{tabular}{lcc}
\hline \multicolumn{1}{c}{ Variabel } & Rataan & Standar Deviasi \\
\hline Produksi Susu $(\mathrm{ml})$ & 848,2 & 228,013 \\
Panjang Badan (cm) & 72,1 & 3,177 \\
Tinggi Badan $(\mathrm{cm})$ & 74,9 & 5,423 \\
Lingkar Dada (cm) & 81,8 & 3,847 \\
Volume Ambing Sebelum Pemerahan $(\mathrm{ml})$ & 902,5 & 226,986 \\
\hline
\end{tabular}

Berdasarkan hasil penelitian, pada produksi susu diperoleh hasil dengan rataan $848,2 \mathrm{ml}$, sesuai dengan pendapat Subhagiana (1998) yang menyatakan bahwa produksi susu kambing PE per ekor $0,787-0,941$ 1/hari. Sodiq dan Abidin (2009) menambahkan bahwa produksi susu yang dihasilkan kambing PE adalah 0,452-2,2 1/ekor/hari. Namun hasil penelitian ini lebih kecil dari pernyataan Blakely dan Bade (1998) yaitu 1,5-3,7 1/ekor/hari. Pada pengukuran volume ambing sebelum pemerahan diperoleh hasil $902,5 \mathrm{ml}$, lebih besar dibandingkan pernyataan Taofik dan Depison (2008) yaitu $438 \mathrm{ml}$

Perbedaan produksi susu tersebut disebabkan oleh beberapa faktor diantaranya faktor genetik dan lingkungan (manajemen pemeliharaan) yang berbeda di setiap peternakan. Menurut Mukhtar (2006), produktivitas kambing perah dipengaruhi oleh beberapa faktor diantaranya faktor genetis seperti jenis ternak, keturunan, umur, hormon, kebuntingan, dan ukuran tubuh serta faktor lingkungan seperti pakan, musim, lama laktasi, pemerahan, penyakit, dan obat-obatan. Pribadiningtyas et al. (2012) menambahkan bahwa produksi susu kambing PE dipengaruhi oleh beberapa hal antara lain mutu genetik, umur induk, ukuran dimensi ambing, bobot hidup, lama laktasi, kondisi iklim setempat, daya adaptasi ternak, dan aktivitas pemerahan.

Pada penelitian ini diperoleh hasil panjang badan, tinggi badan, dan lingkar dada kambing PE 
dengan rataan $72,1 \pm 3,177 \mathrm{~cm}, 74,9 \pm 5,423 \mathrm{~cm}$, $81,8 \pm 3,847 \mathrm{~cm}$, lebih besar dibandingkan data Badan Standarisasi Nasional (2015). Badan Standarisasi Nasional menyatakan bahwa indukan kambing PE yang baik memiliki ukuran minimal pada panjang badan $65 \mathrm{~cm}$, tinggi badan $69 \mathrm{~cm}$, dan lingkar dada $72 \mathrm{~cm}$. Hasil pada penelitian ini sedikit lebih kecil dibandingkan hasil penelitian Febriana et al. (2018), dimana hasil rataan ukuran panjang badan kambing PE sebesar 72,31 cm, tinggi badan sebesar $75,97 \mathrm{~cm}$, dan lingkar dada sebesar $83,75 \mathrm{~cm}$.

Setiawati et al. (2013) menyatakan bahwa pertambahan tinggi pundak dipengaruhi oleh perkembangan tulang kaki tetapi tidak dipengaruhi oleh bobot badan ternak atau gemuk kurusnya ternak tersebut. Menurut Cannas (2004), semakin besar lingkar dada seekor ternak berarti ukuran alat pencernaan ternak semakin besar, sehingga dapat memanfaatkan pakan yang lebih banyak dan mencerna relatif lebih sempurna. Apabila jumlah pakan yang tercerna besar maka produksi susu ternak juga akan ikut meningkat.

Perbedaan hasil tersebut dapat disebabkan adanya perbedaan manajemen pemeliharaan serta lokasi yang berbeda di setiap peternakan sehingga performa kambing juga akan berbeda. Budiarsana (2005) menambahkan bahwa performa ternak di lapangan dipengaruhi oleh beberapa faktor yang kompleks sehingga menyebabkan terjadinya perbedaan hasil pengukuran performa ternak di setiap lokasi dan waktu yang berbeda. Salah satu faktor yang sangat berperan penting dalam produksi susu di peternakan rakyat Mandiri Jaya Bersama dan Yosomukti adalah pakan. Penggunaan bahan pakan yang tidak konstan pada kedua kelompok ternak ini dapat menjadi salah satu penyebab rendahnya produksi susu, terlebih lagi ketersediaan ampas tahu yang tidak tersedia setiap saat sangat mempengaruhi produksi susu. Adriani et al. (2014) menambahkan bahwa kambing yang mendapat pakan cukup secara kualitas dan kuantitas selama laktasi, maka sel kelenjar ambing yang sudah terbentuk akan memproduksi susu secara maksimal karena pakan adalah sumber nutrisi di darah yang akan menjadi prekursor untuk sintesis susu, sehingga pemberian pakan berkualitas pada kambing Peranakan Etawah saat laktasi dapat meningkatkan produksi susu yang dihasilkan.

\section{Korelasi antara Ukuran-Ukuran Tubuh dengan Produksi Susu Kambing PE Betina}

Korelasi antara ukuran-ukuran tubuh (panjang badan, tinggi badan, lingkar dada, dan volume ambing sebelum pemerahan) dengan produksi susu kambing PE betina tersaji pada Tabel 2.

Tabel 2. Korelasi antara ukuran-ukuran tubuh dengan produksi susu kambing PE betina di peternakan rakyat Mandiri Jaya Bersama dan Yosomukti

\begin{tabular}{ccc}
\hline Korelasi Antara & $\begin{array}{c}\text { Koefisien Korelasi } \\
(\mathrm{r})\end{array}$ & Koefisien Determinasi $\left(\mathrm{R}^{2}(\%)\right)$ \\
\hline PB - PS & $0,089^{* *}$ & 0,79 \\
TB - PS & $0,089^{* *}$ & 0,79 \\
LD - PS & $0,184^{* *}$ & 3,38 \\
VASP - PS & $0,815^{* *}$ & 66,42 \\
\hline
\end{tabular}

Keterangan $: \mathrm{PB}=$ Panjang Badan, $\mathrm{TB}=$ Tinggi Badan, $\mathrm{LD}=$ Lingkar Dada, VASP $=$ Volume Ambing Sebelum Pemerahan, PS = Produksi Susu, $* *=$ Signifikan taraf $1 \%(\mathrm{P}<0,01)$.

Tabel 2 menunjukkan bahwa ada hubungan sangat rendah antara panjang badan dan tinggi badan dengan produksi susu yaitu 0,089 dengan nilai determinasi $0,79 \%$ serta lingkar dada sebesar 0,184 dengan nilai determinasi 3,38\%. Namun terdapat korelasi sangat kuat antara volume ambing sebelum pemerahan dengan produksi susu yaitu 0,815 dan nilai determinasi $66,42 \%$. Nilai tersebut diartikan bahwa produksi susu dipengaruhi oleh volume ambing sebelum pemerahan sebesar $66,42 \%$ sedangkan sisanya $(33,58 \%)$ dipengaruhi oleh faktor-faktor lain.

Hasil analisis korelasi ukuran-ukuran tubuh dengan produksi susu meliputi panjang badan dan tinggi badan masing-masing 0,089 serta lingkar dada sebesar 0,184. Hasil tersebut lebih kecil dibandingkan pernyataan Febriana et al. (2018) dimana panjang badan 0,140 ; tinggi badan 0,247; dan lingkar dada 0,196. Berdasarkan hasil tersebut dapat dikatakan bahwa korelasi masingmasing ukuran-ukuran tubuh (panjang badan, tinggi badan, dan lingkar dada) dengan produksi susu memiliki hubungan yang sangat rendah dengan nilai persentase pengaruhnya $\left(R^{2}\right)<5 \%$. Produksi susu lebih banyak dipengaruhi oleh faktor-faktor diluar ukuran-ukuran tubuh $(>95 \%)$ seperti genetik, umur, masa laktasi, iklim, dan manajemen pemeliharaan.

Hubungan yang tidak nyata antara produksi susu dengan panjang badan, tinggi badan, atau lingkar dada pada penelitian ini sesuai dengan 
pernyataan Saputra et al. (2013) yang menyatakan bahwa panjang badan, tinggi badan, dan lingkar dada memiliki hubungan yang tidak nyata dengan produksi susu kambing Sapera. Namun hasil tersebut kurang sesuai dengan pernyataan Jarmuji (2011) dengan hasil terdapat hubungan kuat antara lingkar dada atau bobot badan dengan produksi susu bernilai masing-masing 0,84 dan 0,51. Hubungan antara ukuran tubuh dengan produksi susu mungkin tidak terjadi secara langsung, seperti ukuran tubuh yang dipengaruhi oleh faktor genetis dan lingkungan. Faktor genetis tentunya akan memberikan sumbangsih yang besar terhadap performa yang diturunkan dari induk ke anaknya, sedangkan faktor lingkungan seperti pakan akan mempengaruhi pertumbuhan ternak yang juga berpengaruh pada postur tubuh, bentuk dan volume ambing hingga produksi susu yang dihasilkan. Setiadi et al. (1994) menambahkan bahwa korelasi sangat mungkin terjadi bukan akibat saling mempengaruhi secara langsung, tetapi akibat satu atau lebih faktor lain yang mempengaruhi kedua ciri tersebut, tidak jarang persamaan yang telah didapat kurang sesuai untuk lokasi yang berbeda.

Hubungan antara volume ambing dengan produksi susu pada penelitian ini mendapatkan hasil yang tinggi dengan nilai korelasi 0,815 , lebih besar dari pernyataan
Pribadiningtyas et al. (2012) yaitu 0,650, Taofik dan Depison (2008) yaitu 0,660, dan Habib et al. (2014) yaitu 0,750. Perbedaan hasil tersebut dapat dikarenakan adanya perbedaan manajemen pemeliharaan serta kondisi ternak itu sendiri. Sesuai dengan pernyataan Taofik dan Depison (2008) bahwa faktor lain yang mempengaruhi volume ambing dengan produksi susu kemungkinan berasal dari umur atau periode laktasi kambing.

Ukuran ambing yang semakin besar memberikan indikasi meningkatnya jumlah produksi susu. Hal ini didasari bahwa ambing merupakan organ penampung air susu, dimana jumlah air susu yang ditampung banyak maka akan memberikan perubahan bentuk dan ukuran pada organ ambing. Hal ini sesuai dengan pernyataan Pulina dan Nudda (2004) bahwa semakin besar ambing maka dapat diduga bahwa produksi susu akan semakin tinggi, karena ukuran ambing yang besar akan menampung jaringan alveoli dan sel sekretori lebih banyak sehingga sintesa air susu yang dihasilkan meningkat.

\section{Persamaan Regresi Ukuran-Ukuran Tubuh dengan Produksi Susu Kambing PE Betina}

Persamaan regresi antara ukuran-ukuran tubuh (panjang badan, tinggi badan, lingkar dada, dan volume ambing sebelum pemerahan) dengan produksi susu kambing PE betina dapat dilihat pada Tabel 3.

Tabel 3. Persamaan regresi ukuran-ukuran tubuh dengan produksi susu kambing PE betina di peternakan rakyat Mandiri Jaya Bersama dan Yosomukti

\begin{tabular}{lcc}
\hline \multicolumn{1}{c}{ Produksi Susu dengan Ukuran Tubuh } & Persamaan Regresi & $\begin{array}{c}\text { Determinasi } \\
(\%)\end{array}$ \\
\hline Panjang Badan & $\hat{\mathrm{Y}}_{\mathrm{PB}}=1308,642-6,385 \mathrm{X}_{1}$ & 0,8 \\
Tinggi Badan & $\hat{\mathrm{Y}}_{\mathrm{TB}}=567,072+3,752 \mathrm{X}_{2}$ & 0,8 \\
Lingkar Dada & $\hat{\mathrm{Y}}_{\mathrm{LD}}=1738,093-10,878 \mathrm{X}_{3}$ & 3,4 \\
Volume Ambing Sebelum Pemerahan & $\hat{\mathrm{Y}}_{\mathrm{VASP}}=109,648+0,818 \mathrm{X}_{4}$ & 66,40 \\
Panjang Badan + Tinggi Badan + Lingkar & $\hat{\mathrm{Y}}=172,457-16,322 \mathrm{X}_{1}+5,414 \mathrm{X}_{2}$ & 69,20 \\
Dada + Volume Ambing Sebelum Pemerahan & $+8,361 \mathrm{X}_{3}+0,845 \mathrm{X}_{4}$ & \\
\hline
\end{tabular}

Keterangan: $\hat{Y}=$ Produksi Susu, $X_{1}=$ Panjang Badan, $X_{2}=$ Tinggi Pundak, $X_{3}=$ Lingkar Dada, $\mathrm{X}_{4}=$ Volume Ambing Sebelum Pemerahan

Hasil penelitian menunjukkan bahwa gabungan antara panjang badan, tinggi badan, lingkar dada, dan volume ambing sebelum pemerahan dengan produksi susu memiliki hubungan yang tertinggi dengan nilai determinasi $69,20 \%$ dan persamaan regresi $\hat{\mathrm{Y}}=172,457-16,322 \mathrm{X}_{1}+5,414 \mathrm{X}_{2}+8,361 \mathrm{X}_{3}+$ $0,845 \mathrm{X}_{4}$, sedangkan produksi susu dengan panjang badan atau dengan tinggi badan memiliki nilai determinasi terendah masingmasing $0,8 \%$ dengan persamaan regresi $\hat{\mathrm{Y}}_{\mathrm{PB}}=$
$1308,642-6,385 \mathrm{X}_{1}$ dan $\hat{\mathrm{Y}}_{\mathrm{TB}}=567,072+3,752 \mathrm{X}_{2}$ (Tabel 3).

Volume ambing yang besar mengandung sel sekretori yang besar juga, yang berfungsi untuk mensekresikan susu (Habib et al., 2014). Gall (1980) menambahkan bahwa volume ambing berhubungan dengan jumlah sel sekretori, sehingga semakin besar volume ambing maka semakin bertambah pula sel sekretori yang berfungsi untuk mensintesis susu sampai ke gland cistern. Hal ini berarti bahwa volume ambing dapat digunakan untuk memprediksi produksi 
susu kambing perah, karena semakin besar volume ambing maka produksi susunya semakin meningkat. Sesuai dengan pernyataan Pribadiningtyas et al. (2012) bahwa semakin besar volume ambing maka semakin besar pula produksi susunya. Taofik dan Depison (2008) serta Febriana et al. (2018) menyatakan bahwa terdapat keeratan hubungan yang tinggi antara volume ambing dengan produksi susu. Pernyataan tersebut menunjukan bahwa volume ambing merupakan faktor yang mempengaruhi produksi susu, dalam hal ini dapat dijadikan sebagai acuan oleh para peternak dalam menentukan ternak mana yang memiliki produksi susu tinggi.

\section{SIMPULAN DAN SARAN}

\section{Simpulan}

Volume ambing sebelum pemerahan memiliki hubungan yang kuat dengan produksi susu dimana $r=0,815 ; R^{2}=66,42 \%$; dan persamaan garis regresi $\hat{\mathrm{Y}}_{\mathrm{VASP}}=$ $109,648+0,818 \mathrm{X}_{4}$. Sedangkan peubah panjang badan, tinggi badan, atau lingkar dada berkorelasi sangat rendah dengan produksi susu dengan nilai 0,089; 0,089; dan 0,184. Secara bersama-sama peubah panjang badan, tinggi badan, lingkar dada, dan volume ambing sebelum pemerahan memiliki korelasi yang kuat dengan produksi susu dimana $r=0,832$; $\mathrm{R}^{2}=68,20 \%$; dan persamaan garis regresi $\hat{\mathrm{Y}}=$ $172,457-16,322 \mathrm{X}_{1}+5,414 \mathrm{X}_{2}$ $+8,361 \mathrm{X}_{3}+0,845 \mathrm{X}_{4}$.

\section{Saran}

Peternak sebaiknya menggunakan ukuran volume ambing sebelum pemerahan dalam pendugaan produksi susu kambing PE. Perlu ada penelitian lanjutan mengenai korelasi ukuran-ukuran badan dengan produksi susu kambing Peranakan Etawah betina ditinjau dari banyaknya pemerahan dan pakan yang diberikan.

\section{DAFTAR PUSTAKA}

Adriani, A. Latif, S. Fachri dan I. Sulaksana. 2014. Peningkatan Produksi Dan Kualitas Susu Kambing Peranakan Etawah Sebagai Respon Perbaikan Kualitas Pakan. J. Ilmiah Ilmu-Ilmu Peternakan. 17(1): 15-21.

Badan Standarisasi Nasional. 2015. Kambing PE. SNI. 7352.1-2015. Jakarta.

Blakely, J. dan D. H. Bade. 1998. Ilmu Peternakan. Edisi Keenam. Terjemahan:
B. Srigandono. Gadjah Mada University Press. Yogyakarta.

Budiarsana, I. G. M. 2005. Performan Kambing Peranakan Etawah (PE) di Lokasi Agroekosistem yang Berbeda. Prosiding Seminar Nasional Teknologi Peternakan dan Veteriner. Pusat Penelitian dan Pengembangan Peternakan. Badan Penelitian dan Pengembangan Pertanian. Departemen Pertanian. Bogor.

Cannas, A. 2004. Feeding of Lactating Ewes. In: Pulina G, editor. Dairy Sheep Nutritionl. CABI Publishing. Oxfordshire.

Febriana, D, N., D. W. Harjanti, dan P. Sambodho. 2018. Korelasi Ukuran Badan, Volume Ambing dan Produksi Susu Kambing Peranakan Etawah (PE) di Kecamatan Turi Kabupaten Sleman Yogyakarta. J. IlmuIlmu Peternakan. 28(2): 134-140.

Gall, C. 1980. Relationship Between Body Conformation and Production in Dairy Goats. J. Dairy Science. 63(10): 1768-1781.

Habib, I., T. H. Suprayogi, dan P. Sambodho. 2014. Hubungan antara Volume Ambing, Lama Massage dan Lama Pemerahan terhadap Produksi Susu Kambing Peranakan Ettawa. Animal Agriculture J. 3(1): 8-16.

Jarmuji. 2011. Nilai Korelasi antara Ukuran Badan dan Ambing Induk Domba Lokal Jonggol terhadap Produksi Susu. Agrinak, 1(1): 5255.

Krismanto, Y. 2011. Hubungan Ukuran-Ukuran Tubuh Ternak Kambing Peranakan Etawah Betina terhadap Produksi Susu. Skripsi. Fakultas Peternakan. Institut Pertanian Bogor. Bogor.

Mukhtar, A. 2006. Ilmu Produksi Ternak Perah. Universitas Sebelas Maret Press. Surakarta.

Pabana, T. 2010. Korelasi antara Dimensi Ambing dan Puting dengan Produksi Susu Kambing Peranakan Ettawa (PE). Skripsi. Fakultas Peternakan. Universitas Hasanudin. Makassar.

Pribadiningtyas, P. A., T. H. Suprayogi, dan P. Sambodho. 2012. Hubungan antara Bobot Badan, Volume Ambing terhadap Produksi Susu Kambing Perah Laktasi Peranakan Ettawa. Animal Agricultural J. 1(1): 99105.

Pulina, G. and A. Nudda. 2004. Milk Production. In: Pullina G, editor. Dairy Sheep Nutrition. CABI Publishing. Oxfordshire.

Saputra, Y., Sudewo, A.T. dan Utami, S. 2013. Hubungan antara Lingkar Dada, Panjang Badan, Tinggi Badan dan Lokasi dengan Produksi Susu Kambing Sapera. J. Ilmiah Peternakan 1(3): 1173-1182. 
Setiadi, B., D. Priyanto., B. Sudaryanto, dan Subandriyo. 1994. Pendugaan Bobot Badan melalui Pengukuran Beberapa Ukuran Tubuh pada Domba Persilangan Domba Ekor Gemuk dengan Pejantan Merino. Prosiding Seminar Nasional Sains dan Teknologi Peternakan. Pusat Penelitian dan Pengembangan Peternakan. Badan Penelitian dan Pengembangan Pertanian. Departemen Pertanian. Bogor.

Setiawati, T., P. Sambodho, dan A. Sustiyah. 2013. Tampilan Bobot Badan dan Ukuran Tubuh Kambing Dara Peranakan Ettawa akibat Pemberian Ransum dengan Suplementasi Urea yang Berbeda. Animal Agricultural $J$. 2(2): 8-14.
Sodiq, A. dan Z. Abidin. 2009. Meningkatkan Produksi Susu Kambing Peranakan Etawah. Cetakan Kedua. Agromedia Pustaka. Jakarta.

Subhagiana, I. W. 1998. Keadaan Konsentrasi Progesteron dan Estradiol Selama Kebuntingan, Bobot Lahir dan Jumlah Anak pada Kambing Peranakan Etawah pada Tingkat Produksi Susu yang Berbeda. Tesis Magister Sains. Program Pascasarjana, Institut Pertanian Bogor. Bogor.

Taofik, A. dan Depison. 2008. Hubungan antara Lingkar Perut dan Volume Ambing dengan Kemampuan Produksi Susu Kambing Peranakan Ettawa. J. Ilmiah Ilmu-Ilmu Peternakan, 11(2): 59-74. 